\title{
Emodin, an 11ß-hydroxysteroid dehydrogenase type 1 inhibitor, regulates adipocyte function in vitro and exerts anti-diabetic effect in ob/ob mice
}

\author{
Yue-jing WANG, Su-ling HUANG, Ying FENG, Meng-meng NING, Ying LENG* \\ State Key Laboratory of Drug Research, Shanghai Institute of Materia Medica, Chinese Academy of Sciences, Shanghai 201203, \\ China
}

Aim: Emodin (1,3,8-trihydroxy-6-methylanthraquinone) is a potent and selective inhibitor of 11ß-hydroxysteroid dehydrogenase type 1 $(11 \beta-H S D 1)$ with the ability to ameliorate metabolic disorders in diet-induced obese mice. In the present study, we investigated the effects of emodin on adipocyte function and the underlying mechanisms in vitro, and its anti-diabetic effects in ob/ob mice. Methods: 3T3-L1 adipocytes were used for in vitro studies. 11ß-HSD1A activity was evaluated with a scintillation proximity assay. The adipogenesis, glucose uptake, lipolysis and adiponectin secretion were investigated in 3T3-L1 adipocytes treated with emodin in the presence of active (corticosterone) or inactive glucocorticoid (11-dehydrocorticosterone). For in vivo studies, ob/ob mice were administered emodin ( 25 and $50 \mathrm{mg} \cdot \mathrm{kg}^{-1} \cdot \mathrm{d}^{-1}$, ip) for $26 \mathrm{~d}$. On the last day of administration, the serum was collected and the mesenteric and perirenal fat were dissected for analyses.

Results: Emodin inhibited the 11ß-HSD1 activity in 3T3-L1 adipocytes in concentration- and time-dependent manners (the IC $_{50}$ values were 7.237 and $4.204 \mu \mathrm{mol} / \mathrm{L}$, respectively, after 1 and $24 \mathrm{~h}$ treatment. In 3T3-L1 adipocytes, emodin (30 $\mu \mathrm{mol} / \mathrm{L})$ suppressed 11-dehydrocorticosterone-induced adipogenesis without affecting corticosterone-induced adipogenesis; emodin (3 $\mu \mathrm{mol} / \mathrm{L}) \mathrm{reduced}$ 11-dehydrocorticosterone-stimulated lipolysis, but had no effect on corticosterone-induced lipolysis. Moreover, emodin (3 $\mu$ mol/L) partly reversed the impaired insulin-stimulated glucose uptake and adiponectin secretion induced by 11-dehydrocorticosterone but not those induced by corticosterone. In ob/ob mice, long-term emodin administration decreased 11ß-HSD1 activity in mesenteric adipose tissues, lowered non-fasting and fasting blood glucose levels, and improved glucose tolerance.

Conclusion: Emodin improves the inactive glucocorticoid-induced adipose tissue dysfunction by selective inhibition on $11 \beta$-HSD1 in adipocyte in vitro and improves glycemic control in ob/ob mice.

Keywords: emodin; 11ß-hydroxysteroid dehydrogenase type 1; adipocyte; glucocorticoid; type 2 diabetes; ob/ob mice

Acta Pharmacologica Sinica (2012) 33: 1195-1203; doi: 10.1038/aps.2012.87; published online 27 Aug 2012

\section{Introduction}

Adipose tissue plays a key role in regulating energy balance and glucose homeostasis. As an energy storage depot, adipose tissue responds to the body's metabolic signaling by regulating lipid storage and mobilization. Adipocytes release free fatty acid (FFA) as a nutrient source when glucose is limiting, whereas they store abundant energy as triglycerides in energy excess states. Insulin resistance can elevate the FFA level, and excessive FFA induces a deterioration in the metabolic state by accelerating liver glucose output and by inhibiting glucose uptake by peripheral tissues and the generation of reactive oxygen system (ROS), which, in turn, aggravates insulin resis-

\footnotetext{
* To whom correspondence should be addressed.

E-mail yleng@mail.shcnc.ac.cn

Received 2012-05-01 Accepted 2012-05-28
}

tance $^{[1]}$. Adipose tissue is an endocrine organ that releases several adipokines, such as leptin, adiponectin, visfatin, omentin, and resistin, to regulate glucose homeostasis and whole body insulin sensitivity ${ }^{[1]}$. Thus, adipocyte dysfunction is thought to be involved in the pathogenesis of obesity and metabolic diseases such as type 2 diabetes $^{[2]}$.

Glucocorticoid (GC) is an insulin-antagonizing hormone that stimulates hepatic glucose production and suppresses insulin-mediated glucose uptake in peripheral tissues such as adipose tissue and skeletal muscle. Glucocorticoid excess, which is well-characterized in Cushing's syndrome, produces central obesity and several clinical features associated with insulin resistance, such as type 2 diabetes, dyslipidemia, and hypertension $^{[3]}$. The action of glucocorticoid on target tissue is determined not only by the circulating glucocorticoid level but also by the local glucocorticoid activation, which is regulated 
by the $11 \beta$-hydroxysteroid dehydrogenase type 1 (11ß-HSD1) and $11 \beta-H S D 2.11 \beta-H S D 1$, which is highly expressed in the liver, adipose tissue, gonads and brain, catalyze the activation of glucocorticoid (cortisol in human and corticosterone in rodents) from inactive 11-kero steroids (cortisone in human and 11-dehydrocorticosterone in rodents). This process amplifies local glucocorticoid action, whereas $11 \beta-H S D 2$ is predominantly expressed in aldosterone-sensitive target tissues (in the kidney, colon, salivary glands and placenta) and catalyzes the opposite reaction ${ }^{[4]}$.

Excess glucocorticoid in adipocytes decreases insulininduced glucose uptake, promotes FFA secretion and affects adipokine profiles, thus causing insulin resistance ${ }^{[5]}$. Therefore, $11 \beta-H S D 1$ is expected to play an important role in the regulation of glucose and lipid metabolism in adipose tissue. Several human studies have reported two- to three-fold increases in 11 $\beta$-HSD1 activity in the adipose tissue of obese individuals, and the expression of $11 \beta$-HSD 1 in adipose tissue was positively correlated with the degree of obesity ${ }^{[6,7]}$. The contribution of $11 \beta-H S D 1$ to the development of insulin resistance and obesity has been further confirmed in animal studies. Mice overexpressing adipose-specific 11 $\beta$-HSD1 showed increased corticosterone in adipose tissue and developed insulin resistance, central obesity, hyperlipidemia, and other features of metabolism syndrome ${ }^{[8,9]}$, whereas mice overexpressing liver-specific $11 \beta$-HSD1 only showed mild insulin resistance and dyslipidemia ${ }^{[10]}$. 11ß-HSD1 knockout mice showed improved glucose tolerance, an elevated HDL, and protection from weight gain during a high-fat diet ${ }^{[11-13]}$. Moreover, overexpressing $11 \beta-H S D 2$ to inactivate glucocorticoid in the adipose tissue of mice caused decreased food intake and improved glucose tolerance and insulin sensitivity under conditions of a high-fat diet ${ }^{[14]}$. Considering the above findings, the pharmacological inhibition of 11ß-HSD1, especially in adipose tissue, could be a therapy for type 2 diabetes or metabolic diseases.

Emodin is an anthraquinone compound isolated mainly from the root and rhizome of Rheum palmatum. It demonstrates a variety of biological activities, such as anti-virus activities, anti-tumor activities, anti-inflammatory activities, and immune suppression, and it can also serve as a potential agent in therapy for liver cirrhosis, diabetic nephropathy and atherosclerosis ${ }^{[15-20]}$. Our previous study showed that emodin is a potent and selective $11 \beta$-HSD1 inhibitor and can ameliorate metabolic disorders in diet-induced obese mice ${ }^{[21]}$. In the present study, we investigated the effect of emodin on adipocyte function and the underlying mechanisms involving inhibition of $11 \beta$-HSD1. The anti-diabetic effect of emodin was also investigated in $o b / o b$ mice, a genetic animal model of type 2 diabetes.

\section{Materials and methods Materials}

Emodin was purchased from Nanjing Zelang Medical Technology Co Ltd (Nanjing, China). Corticosterone, dexamethasone, insulin, glycyrrhetinic acid and 3-isobutyl-1-methylxanthine were purchased from Sigma (St Louis, MO, USA). 11-Dehydrocorticosterone was purchased from Steraloids (Newport, RI, USA). Fetal bovine serum (FBS), penicillin/streptomycin, HEPES and high glucose Dulbecco's modified Eagle's medium (DMEM) were purchased from GibcoBRL (Grand island, NY, USA). TRIzol Reagent was purchased from Invitrogen (Carlsbad, CA, USA). The M-MLV reverse transcriptional enzyme and SYBR ${ }^{\circledR}$ Premix Ex Taq ${ }^{\mathrm{TM}}$ were obtained from Takara (Dalian, China). All the primers were synthesized by Sangon Corporation (Shanghai, China). [1,2-(n) $\left.{ }^{3} \mathrm{H}\right]$-Cortisone was obtained from Amersham (Buckinghamshire, UK). SPA beads were purchased from GE (Piscataway, NJ, USA). SuperBlock Blocking Buffer was obtained from Pierce (Rockford, IL, USA). The murine monoclonal anti-cortisol antibody was purchased from East Coast Biologics (North Berwick, ME, USA).

\section{T3-L1 cell culture and differentiation}

3T3-L1 preadipocytes were cultured and differentiated as previously described $^{[22]}$. In brief, 3T3-L1 preadipocytes were maintained at $\sim 70 \%$ confluence in DMEM supplemented with 10\% FBS, $25 \mathrm{mmol} / \mathrm{L}$ glucose and antibiotics (DMEM/ FBS). Cells were grown for $2 \mathrm{~d}$ post-confluence and cultured in DMEM/FBS supplemented with $1 \mu \mathrm{mol} / \mathrm{L}$ insulin, 0.25 $\mu \mathrm{mol} / \mathrm{L}$ dexamethasone, and $0.5 \mathrm{mmol} / \mathrm{L} 3$-isobutyl-1-methylxanthine for $3 \mathrm{~d}$. The medium was replaced with DMEM/ FBS supplemented with only $1 \mu \mathrm{mol} / \mathrm{L}$ insulin for $3 \mathrm{~d}$ and then DMEM/FBS alone for $2 \mathrm{~d}$. Cytoplasmic triacylglycerol droplets were visible on d 5 after initiation of differentiation. The differentiated cells were used when $\sim 90 \%$ of the cells showed an adipocyte phenotype.

\section{1ß-HSD1 enzyme activity assay}

The reductase activity of $11 \beta$-HSD1 in intact 3T3-L1 adipocytes was determined by measuring the rate of conversion of cortisone to cortisol. 3T3-L1 adipocytes were incubated for $1 \mathrm{~h}$ at $37^{\circ} \mathrm{C}$ in serum-free DMEM containing $6.25 \mathrm{nmol} / \mathrm{L}[1,2-(\mathrm{N})$ ${ }^{3} \mathrm{H}$ ]-cortisone and different concentrations of emodin, according to experimental design, and 0.1\% DMSO was set as the vehicle control. To explore the effect of emodin on 11 $\beta$-HSD1 reductase activity after $24 \mathrm{~h}$ of treatment, the adipocytes were pretreated with emodin for $23 \mathrm{~h}$ before incubation. At the end of the incubation, $80 \mu \mathrm{L}$ of medium was pipetted into a transparent bottom 96-well plate, and $35 \mu \mathrm{L}$ of SuperBlock Blocking Buffer containing $10 \mathrm{~g} / \mathrm{L}$ of protein A-coated yttrium silicate beads and $3 \mathrm{mg} / \mathrm{L}$ of anti-cortisol antibodies was added. The mixtures were shaken in the dark for $2 \mathrm{~h}$ and then used for liquid scintillation readings.

\section{Adipogenesis measurement}

To observe the effect of emodin on adipocyte adipogenesis, 3T3-L1 preadipocytes were initiated to differentiate with 1 $\mu \mathrm{mol} / \mathrm{L}$ insulin, $0.5 \mathrm{mmol} / \mathrm{L}$ IBMX and different types of glucocorticoids $(0.25 \mu \mathrm{mol} / \mathrm{L}$ dexamethasone, $0.25 \mu \mathrm{mol} / \mathrm{L}$ 11-DHC or $0.25 \mu \mathrm{mol} / \mathrm{L}$ corticosterone). The emodin or vehicle control containing $0.1 \%$ DMSO was added on the first day of differentiation, and the medium was changed every 
$2 \mathrm{~d}$ until d 8. The triglyceride content of cells was measured on $\mathrm{d} 8$. After washing with ice-cold PBS, the adipocytes were collected and sonicated in distilled water. The triglyceride content of the cell lysate was measured using the GPO-PAP method, and the absorbance was monitored at $546 \mathrm{~nm}$ in a spectrophotometer.

\section{Glucose uptake}

3T3-L1 adipocytes were pretreated with $3 \mu \mathrm{mol} / \mathrm{L}$ emodin for $2 \mathrm{~h}$ and then incubated with $10 \mathrm{nmol} / \mathrm{L}$ corticosterone, $10 \mathrm{nmol} / \mathrm{L} 11-\mathrm{DHC}$ or $0.1 \%$ ethanol for another $24 \mathrm{~h}$. The medium containing $0.1 \%$ DMSO was used as the vehicle. At the last $0.5 \mathrm{~h}$ of treatment, glucose uptake was determined. The adipocytes were washed twice with pre-warmed $\left(37^{\circ} \mathrm{C}\right)$ PBS and incubated with Krebs-BSA buffer $(140 \mathrm{mmol} / \mathrm{L} \mathrm{NaCl}$, $5 \mathrm{mmol} / \mathrm{L} \mathrm{KCl}, 2.5 \mathrm{mmol} / \mathrm{L} \mathrm{MgSO}_{4}, 1 \mathrm{mmol} / \mathrm{L} \mathrm{CaCl}_{2}, 20$ $\mathrm{mmol} / \mathrm{L}$ HEPES, and $0.5 \% \mathrm{BSA}, \mathrm{pH}$ 7.4) with or without insulin (basal state) for $25 \mathrm{~min}$, followed by the addition of 0.05 $\mathrm{mmol} / \mathrm{L} 2$-deoxy- $D$-glucose and $1.85 \times 10^{4} \mathrm{~Bq} / \mathrm{mL} 2$-deoxy$D-\left[1,2-{ }^{3} \mathrm{H}\right]$ glucose for $5 \mathrm{~min}$. The assay was terminated by washing the cells three times with ice-cold PBS. The cells were solubilized with $0.1 \%$ Triton $\mathrm{X}-100$, and radioactivity was determined in a liquid scintillation counter (Beckman LS6500, Fullerton, CA, USA). Total cellular protein concentration was measured by the Bradford method (BioRad, Richmond, CA, USA). Glucose uptake assays were performed in duplicate at least three times.

\section{Lipolysis}

3T3-L1 adipocytes were pretreated with $3 \mu \mathrm{mol} / \mathrm{L}$ emodin or $0.1 \%$ DMSO for $2 \mathrm{~h}$ and then incubated with $10 \mathrm{nmol} / \mathrm{L}$ corticosterone, $10 \mathrm{nmol} / \mathrm{L} 11-\mathrm{DHC}$ or $0.1 \%$ ethanol in phenolred free DMEM for another $48 \mathrm{~h}$. The medium was collected, and the free glycerol (index of lipolysis) was measured using a Free Glycerol Determination Kit (Sigma, St Louis, MO, USA).

\section{Adiponectin release}

3T3-L1 adipocytes were pretreated with $3 \mu \mathrm{mol} / \mathrm{L}$ emodin or $0.1 \%$ DMSO for $2 \mathrm{~h}$ in serum-free DMEM and were then incubated with $50 \mathrm{nmol} / \mathrm{L}$ corticosterone, $50 \mathrm{nmol} / \mathrm{L}$ 11-DHC or $0.1 \%$ ethanol for another $48 \mathrm{~h}$. After treatment, the cell medium was collected and added to $5 \times$ Laemmli Buffer. The medium was then degenerated at $56^{\circ} \mathrm{C}$ for $20 \mathrm{~min}$. Equal amounts of the medium were subjected to $10 \%$ SDS polyacrylamide gel electrophoresis, and the separated proteins were transferred to polyvinylidene difluoride membranes. Then, the membranes were blocked for $1 \mathrm{~h}$ with $7.5 \%$ non-fat milk at room temperature and incubated with an antibody against adiponectin (R\&D, MN, USA) at $4{ }^{\circ} \mathrm{C}$. After overnight incubation with the primary antibody, the blots were repeatedly washed in 0.1\% TBS-Tween and incubated with a 1:10000 dilution of an HRP-conjugated secondary antibody in $0.1 \%$ TBS-Tween for $1 \mathrm{~h}$. Following further washes, proteins were detected using an ECL Plus Western Blotting Detection System (Amersham, Arlington Heights, IL, USA) and quantified by densitometry.

\section{Animals and treatments}

B6.V-Lep ${ }^{o b} / \mathrm{Lep}^{o b}(o b / o b)$ mice and their lean littermates ${ }^{+/+}$(from Jackson Laboratory, Bar Harbor, ME, USA) were bred at the Shanghai Institute of Materia Medica (SIMM), Chinese Academy of Sciences. The animals were maintained under a 12-h light-dark cycle with free access to water and food. The animal experiments were approved by the Animal Care and Use Committee, Shanghai Institute of Materia Medica, Chinese Academy of Sciences.

Based on fasting blood glucose values (first criterion) and initial body weights (second criterion), the $o b / o b$ mice were assigned to four groups. The $o b / o b$ mice were subjected to intraperitoneal injection treatment twice daily with the vehicle $(0.5 \%$ Tween 80$)$, emodin $(25 \mathrm{mg} / \mathrm{kg})$ or emodin $(50 \mathrm{mg} / \mathrm{kg})$ for $26 \mathrm{~d}$. We subjected the fourth group of $o b / o b$ mice to pair feeding (providing the mice each day with the amount of food eaten by the freely fed mice treated with $50 \mathrm{mg} / \mathrm{kg}$ of emo$\mathrm{din})$ on $\mathrm{d} 7$. The lean mice were treated with the vehicle $(0.5 \%$ Tween 80 ). The blood glucose levels were measured via blood drops obtained by clipping the tail of the mice using a ONE TOUCH BASIC plus Glucose Monitor (Lifescan, Milpitas, CA, USA). The food intake and body weight of the animals were recorded every $3 \mathrm{~d}$. A glucose tolerance test was performed for mice deprived of food for $5 \mathrm{~h}(2.5 \mathrm{~g} / \mathrm{kg}$ of glucose administered by gavage) on $\mathrm{d} 20$ of the treatment. On the last day of administration, the mice were anaesthetized with an ip injection of sodium pentobarbital $(40 \mathrm{mg} / \mathrm{kg})$. The serum was collected for the determination of triacylglycerol, cholesterols and the non-esterified free fatty acid (NEFA) concentration. The mesenteric and perirenal fat were dissected, weighed, immediately frozen in liquid nitrogen and stored at $-80^{\circ} \mathrm{C}$.

\section{Real-time PCR}

The mesenteric fat was homogenized in TRIZOL solution, and the total mRNA was extracted following the manufacturer's instructions. One microgram of total mRNA was reverse-transcribed in a $20-\mu \mathrm{L}$ reaction mixture containing 4 $\mu \mathrm{L} 5 \times$ PrimeScript Buffer, $1 \mu \mathrm{L}$ Primescript RT Enzyme Mix I, $1 \mu \mathrm{L}$ Random 6 mers $(100 \mu \mathrm{mol} / \mathrm{L}), 1 \mu \mathrm{L}$ Oligo dT Primer (50 $\mu \mathrm{mol} / \mathrm{L})$, and $11 \mu \mathrm{L}$ RNAse-free $\mathrm{H}_{2} \mathrm{O}$. The mixture was incubated at $37^{\circ} \mathrm{C}$ for $15 \mathrm{~min}$, then at $85^{\circ} \mathrm{C}$ for $5 \mathrm{~s}$. Then, real-time PCR was performed in an ABI 7500 Fast Real-Time PCR System (Applied Biosystems, CA, USA) using the SYBR ${ }^{\circledast}$ Premix Ex Taq ${ }^{\mathrm{TM}}$, and $2 \mu \mathrm{L}$ of cDNA was amplified in a $25-\mu \mathrm{L}$ reaction mixture containing $12.5 \mu \mathrm{L}$ of the SYBR Premix Ex Taq, $0.5 \mu \mathrm{L}$ of the forward primer $(10 \mu \mathrm{mol} / \mathrm{L}), 0.5 \mu \mathrm{L}$ of the reverse primers $(10 \mu \mathrm{mol} / \mathrm{L}), 0.5 \mu \mathrm{L}$ of the ROX Reference Dye II, and $9 \mu \mathrm{L}$ of $\mathrm{dH}_{2} \mathrm{O}$. The amplifications were as follows: $95^{\circ} \mathrm{C}$ for $30 \mathrm{~s}$, followed by 40 cycles at $95^{\circ} \mathrm{C}$ for $5 \mathrm{~s}, 57^{\circ} \mathrm{C}$ for $20 \mathrm{~s}$, and $72^{\circ} \mathrm{C}$ for $15 \mathrm{~s}$. The forward and reverse primers for adiponectin are 5'-AATCATTATGACGGCAGCAC-3' and 5'-CCAGATGGAGGAGCACAGAG-3', respectively; those for PPARY are 5'-GGCCATCCGAATTTTTCAAG-3' and 5'-GGGATATTTTTGGCATACTCTGTGA- $3^{\prime}$, respectively; and those for $\beta$-actin are $5^{\prime}$-TGCTGTCCCTGTATGCCTCTG- ${ }^{\prime}$ ' and $5^{\prime}$-TTGATGTCACGCACGATTTCC-3', respectively. The reverse-tran- 
scribed cDNA samples were amplified, and cycle threshold $\left(C_{t}\right)$ values were determined. The mRNA levels of adiponectin were normalized to the mRNA levels of the housekeeping gene $\beta$-actin. The comparative $C_{t}$ method $\left(2^{-\Delta \Delta C t}\right)$ was used to analyze the differences in the level of adiponectin mRNA between each group.

\section{$11 \beta$-HSD1 activity assay in mesenteric fat}

A weight of $200 \mathrm{mg}$ of mesenteric fat was homogenized in $200 \mu \mathrm{L}$ of cold homogenization buffer $\left(20 \mathrm{mmol} / \mathrm{L} \mathrm{Na}_{2} \mathrm{HPO}_{4}\right.$, $5 \%$ glycerol, $1 \mathrm{mmol} / \mathrm{L}$ EDTA, pH 7.0) at $4{ }^{\circ} \mathrm{C}$. The protein concentration of homogenate was determined using the Bradford method. A total of $10 \mu \mathrm{g}$ of homogenate was pipetted into 96-well microtitre plates, and $70 \mu \mathrm{L}$ of buffer $(25 \mathrm{nmol} / \mathrm{L}$ [1,2-(N) $\left.{ }^{3} \mathrm{H}\right]$-cortisone, $1.25 \mathrm{mmol} / \mathrm{L} \mathrm{NADPH}$ and $150 \mathrm{mmol} / \mathrm{L}$ HEPES, pH 7.4) was added. The microtitre plates were shaken in the dark at $37^{\circ} \mathrm{C}$ at 140 rounds per minute for $1 \mathrm{~h}$. Then, $35 \mu \mathrm{L}$ of SuperBlocking buffer $(10 \mathrm{~g} / \mathrm{L}$ of protein A-coated yttrium silicate beads, $3 \mathrm{~g} / \mathrm{L}$ of anti-cortisol antibody and 314 $\mu \mathrm{mol} / \mathrm{L}$ of glycyrrhetinic acid) was added. After shaking for another $2 \mathrm{~h}$, the amount of $\left[1,2-(\mathrm{N})^{3} \mathrm{H}\right]$-cortisol generated in the $11 \beta$-HSD1 reaction was captured by beads and determined in a microplate liquid scintillation counter.

\section{Statistical analysis}

The results are expressed as the mean \pm SEM. The differences between the two groups were analyzed by Student's $t$-test. Statistical analysis was carried out using the Prism program from GraphPad Software. Values of $P<0.05$ were considered statistically significant.

\section{Results}

Emodin inhibited 11ß-HSD1 activity in 3T3-L1 adipocytes

Emodin showed strong inhibitory effects on $11 \beta$-HSD1 activity in 3T3-L1 adipocytes. The $\mathrm{IC}_{50} \mathrm{~s}$ were 7.237 and $4.204 \mu \mathrm{mol} / \mathrm{L}$ after $1 \mathrm{~h}$ and $24 \mathrm{~h}$ of treatment, respectively (Figure $1 \mathrm{~A}$ and 1B).

\section{Emodin regulated adipogenesis and energy metabolism in 3T3-} L1 cells

It is well documented that glucocorticoids promote preadipocyte differentiation. The triglyceride content of adipocytes was used as a marker of the adipogenesis of 3T3-L1 cells. We found that all active glucocorticoids (dexamethasone and corticosterone) and inactive glucocorticoids (11-dehydrocorticosterone, 11-DHC) enhanced adipogenesis in 3T3-L1 preadipocytes. Incubation with $30 \mu \mathrm{mol} / \mathrm{L}$ of emodin reduced the triglyceride levels of 3T3-L1 adipocytes induced by 11-DHC by $19.8 \%(P<0.01)$, but it had no significant effect on the triglyceride levels in 3T3-L1 adipocytes treated with dexamethasone or corticosterone. Therefore, emodin suppressed inactive glucocorticoid-induced adipogenesis but not active glucocorticoid-induced adipogenesis in 3T3-L1 cells, which might be mediated by the inhibition of $11 \beta$-HSD1 activity (Figure 2A).

To determine whether emodin affects lipolysis through $11 \beta$ HSD1 inhibition, 11-DHC and corticosterone were used to
A
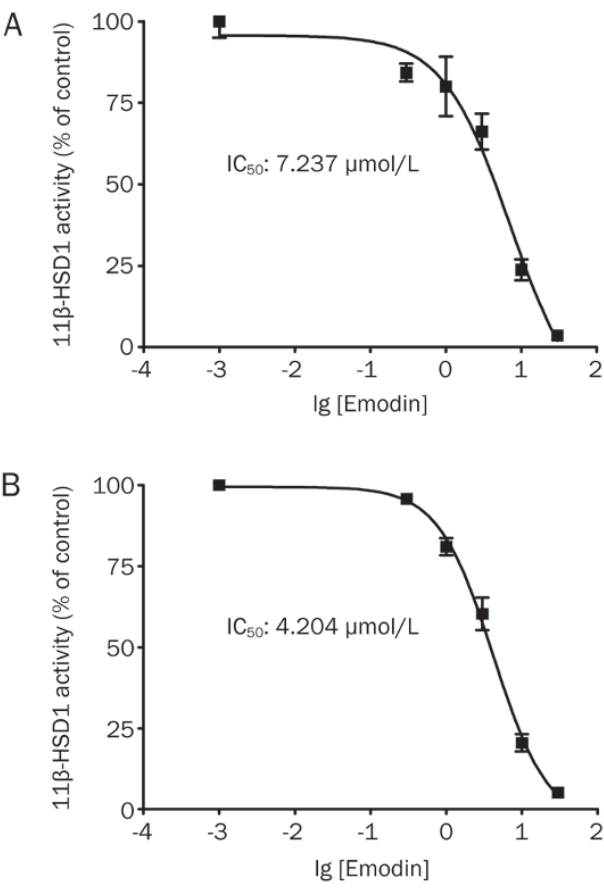

Figure 1. Emodin inhibited 11ß-HSD1 activity in 3T3-L1 adipocytes after $1 \mathrm{~h}(\mathrm{~A})$ or $24 \mathrm{~h}$ (B) of treatment. Differentiated 3T3-L1 adipocytes were incubated with the indicated concentrations of emodin or $0.1 \%$ DMSO for $1 \mathrm{~h}$ or $24 \mathrm{~h}$. 11ß-HSD1 enzyme activity was determined by scintillation proximity assay. Each point represents the mean \pm SEM. $n=3$.

induce lipolysis, and the effects of emodin were studied. Figure $2 \mathrm{~B}$ indicates that $11-\mathrm{DHC}$ and corticosterone significantly increased the glycerol release by $17.8 \%$ and $18.5 \%(P<0.01)$, respectively. Incubation with $3 \mu \mathrm{mol} / \mathrm{L}$ of emodin significantly decreased the glycerol release induced by 11-DHC but not by corticosterone. These results suggest that emodin suppressed lipolysis by inhibiting $11 \beta$-HSD1 activity.

Both 11-DHC and corticosterone attenuated insulinstimulated glucose uptake in 3T3-L1 adipocytes (Figure 2C). Incubation with $3 \mu \mathrm{mol} / \mathrm{L}$ of emodin significantly reversed the impaired insulin-stimulated glucose uptake induced by 11-DHC. Although emodin treatment alone caused an $11.2 \%$ reduction in insulin-stimulated glucose uptake, it increased the insulin-stimulated glucose uptake by $17.7 \%$ when compared with 11-DHC-treated group. However, emodin had no effect on the impaired-insulin stimulated glucose uptake induced by corticosterone (Figure 2C).

Both 11-DHC and corticosterone significantly decreased adiponectin release from 3T3-L1 adipocytes. The reduced adiponectin secretion caused by 11-DHC was partly reversed by treatment with $3 \mu \mathrm{mol} / \mathrm{L}$ of emodin, whereas emodin exerted no effect on the impaired adiponectin secretion induced by corticosterone (Figure 2D).

Emodin suppressed 11ß-HSD1 activity in adipose tissue and ameliorated metabolic disorders in ob/ob mice

To evaluate the long-term effect of emodin on metabolic disor- 
A

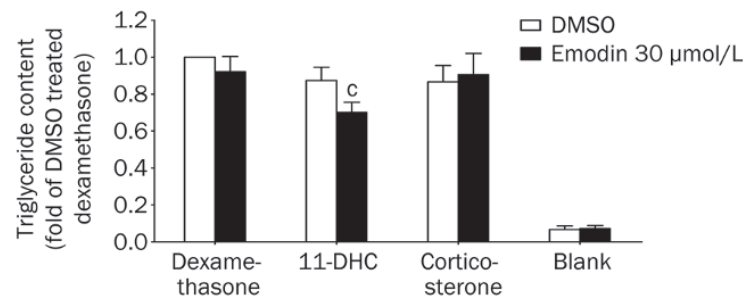

B

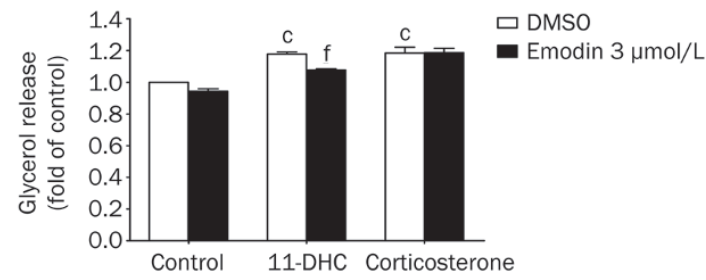

C
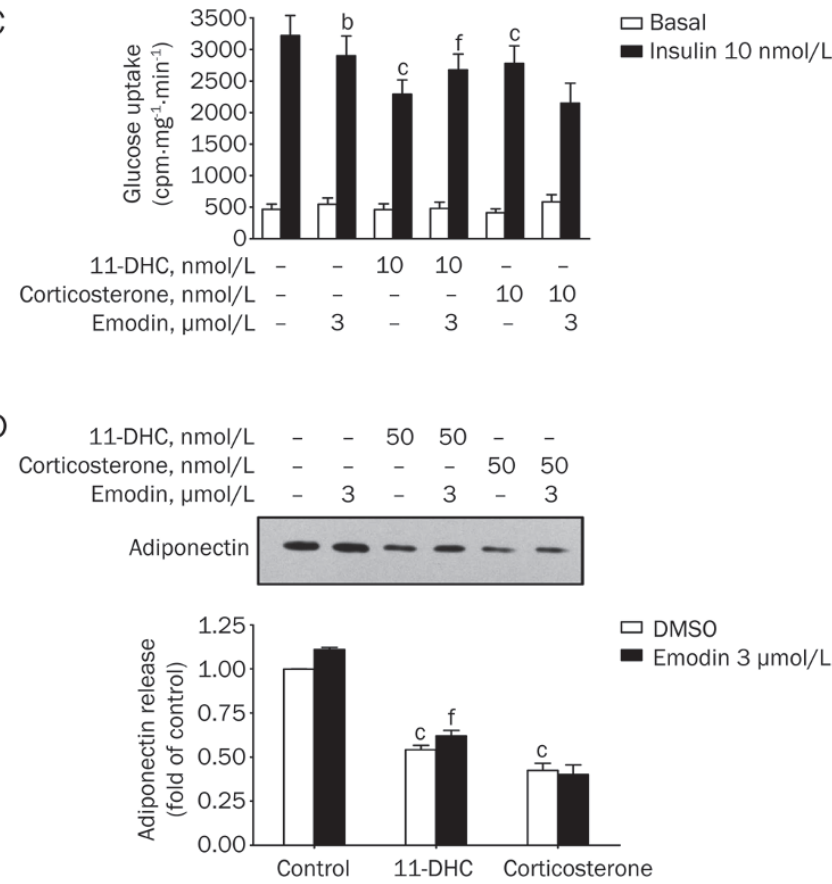

Figure 2. Emodin regulated adipogenesis and energy metabolism in 3T3-L1 adipocytes. (A) Emodin inhibited the adipogenesis induced by 11-DHC (an inactive glucocorticoid) but not by corticosterone (an active glucocorticoid). The values are expressed as the fold increase over the values for the dexamethasone-treated DMSO group. ${ }^{\circ} P<0.01$ vs DMSOtreated 11-DHC group; $n=4$. (B) Emodin inhibited the glycerol release induced by $10 \mathrm{nmol} / \mathrm{L} 11-\mathrm{DHC}$ but not by $10 \mathrm{nmol} / \mathrm{L}$ corticosterone. The values are expressed as the fold increase over the values for the DMSOtreated control group. ${ }^{\mathrm{C}} P<0.01$ vs DMSO-treated control group, ${ }^{\mathrm{f}} P<0.01$ vs DMSO-treated 11-DHC group; $n=3$. (C) Emodin significantly reversed the impaired insulin-stimulated glucose uptake induced by 11-DHC but not by corticosterone. ${ }^{\mathrm{b}} P<0.05,{ }^{\mathrm{c}} P<0.01$ vs insulin-stimulated control group, ${ }^{\mathrm{f}} P<0.01$ vs insulin stimulated $11-\mathrm{DHC}$ group; $n=6$. (D) $11-\mathrm{DHC}$ - but not corticosterone-impaired adiponectin release was reversed by $3 \mu \mathrm{mol} / \mathrm{L}$ of emodin in 3T3-L1 adipocytes. Values are expressed as the fold increase over the values for the DMSO-treated control group. ${ }^{\circ} P<0.01$ vs DMSOtreated control group, ${ }^{\mathrm{f}} P<0.01$ vs DMSO-treated 11-DHC group; $n=3$. ders, $o b / o b$ mice were treated twice daily with 25 or $50 \mathrm{mg} / \mathrm{kg}$ of emodin by intraperitoneal injection for $26 \mathrm{~d}$. The enzymatic activity of $11 \beta-H S D 1$ in mesenteric fat was measured at the end of the experiment. As shown in Figure 3, a significant decrease in $11 \beta-H S D 1$ activity, by $44.5 \%$, was observed in the mesenteric adipose tissues of $o b / o b$ mice treated with $50 \mathrm{mg} / \mathrm{kg}$ of emodin $(P<0.05)$.

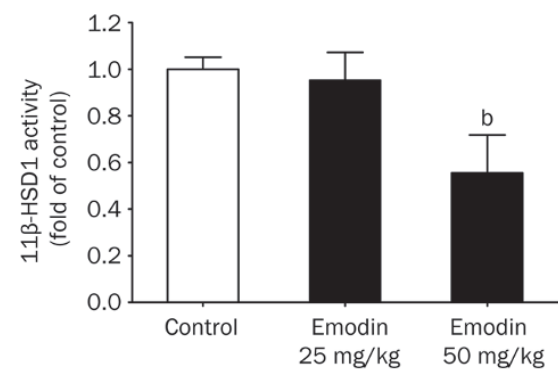

Figure 3. Emodin suppressed $11 \beta-H S D 1$ activity in the mesenteric fat of ob/ob mice. $O b / o b$ mice were subjected to intraperitoneal injection treatment twice daily with vehicle (0.5\% Tween 80$), 25 \mathrm{mg} / \mathrm{kg}$ emodin or $50 \mathrm{mg} / \mathrm{kg}$ emodin for $26 \mathrm{~d}$. 11ß-HSD1 activity in the mesenteric fat was measured by SPA at the end of the treatment period. Values are expressed as fold of the values for the vehicle group. ${ }^{\text {b }} P<0.05$ vs vehicle group; $n=6$.

The genetic type 2 diabetic $o b / o b$ mice showed obesity, hyperglycemia, dyslipidemia and insulin resistance. Longterm treatment with emodin significantly decreased the random-fed and fasting blood glucose levels in $o b / o b$ mice, whereas the pair-fed group of mice showed no significant changes in blood glucose levels. As shown in Figures $4 \mathrm{~A}$ and $4 \mathrm{~B}, 16$ or $20 \mathrm{~d}$ of treatment with $50 \mathrm{mg} / \mathrm{kg}$ of emodin significantly reduced the random-fed blood glucose concentrations in $o b / o b$ mice by $32.53 \%$ and $32.68 \%(P<0.05)$, respectively, and the fasting blood glucose levels of $o b / o b$ mice were also decreased by $38.29 \%(P<0.01)$ and $31.61 \%(P<0.05)$, respectively, when compared with the vehicle control mice. After $20 \mathrm{~d}$ of treatment with $50 \mathrm{mg} / \mathrm{kg}$ of emodin, glucose tolerance was improved. The emodin-treated mice exhibited significant reductions in blood glucose levels at 15, 60, and $120 \mathrm{~min}$ following an oral glucose challenge, and the glucose $\mathrm{AUC}_{0-120 \text { min }}$ value decreased by $29.11 \%$ when compared with the vehicle control group (Figure $4 \mathrm{C}$ and $4 \mathrm{D}, P<0.05$ ). There was no significant difference in the blood glucose level or the $\mathrm{AUC}_{0-120 \mathrm{~min}}$ value between the emodin pair-fed and vehicle control groups. Moreover, the random-fed, fasting blood glucose levels at the treatments on d 16 and d 20 and the blood glucose levels and $\mathrm{AUC}_{0-120 \text { min }}$ values in OGTT of the $50-\mathrm{mg} / \mathrm{kg}$ emodin-treated group were significantly lower than in the pair-fed group $(P<0.05, P<0.01)$.

Emodin also improved the lipid profiles in $o b / o b$ mice. After $26 \mathrm{~d}$ of treatment with $50 \mathrm{mg} / \mathrm{kg}$ of emodin, the serum triglyceride was significantly reduced by $26.0 \%(P<0.01)$ compared 

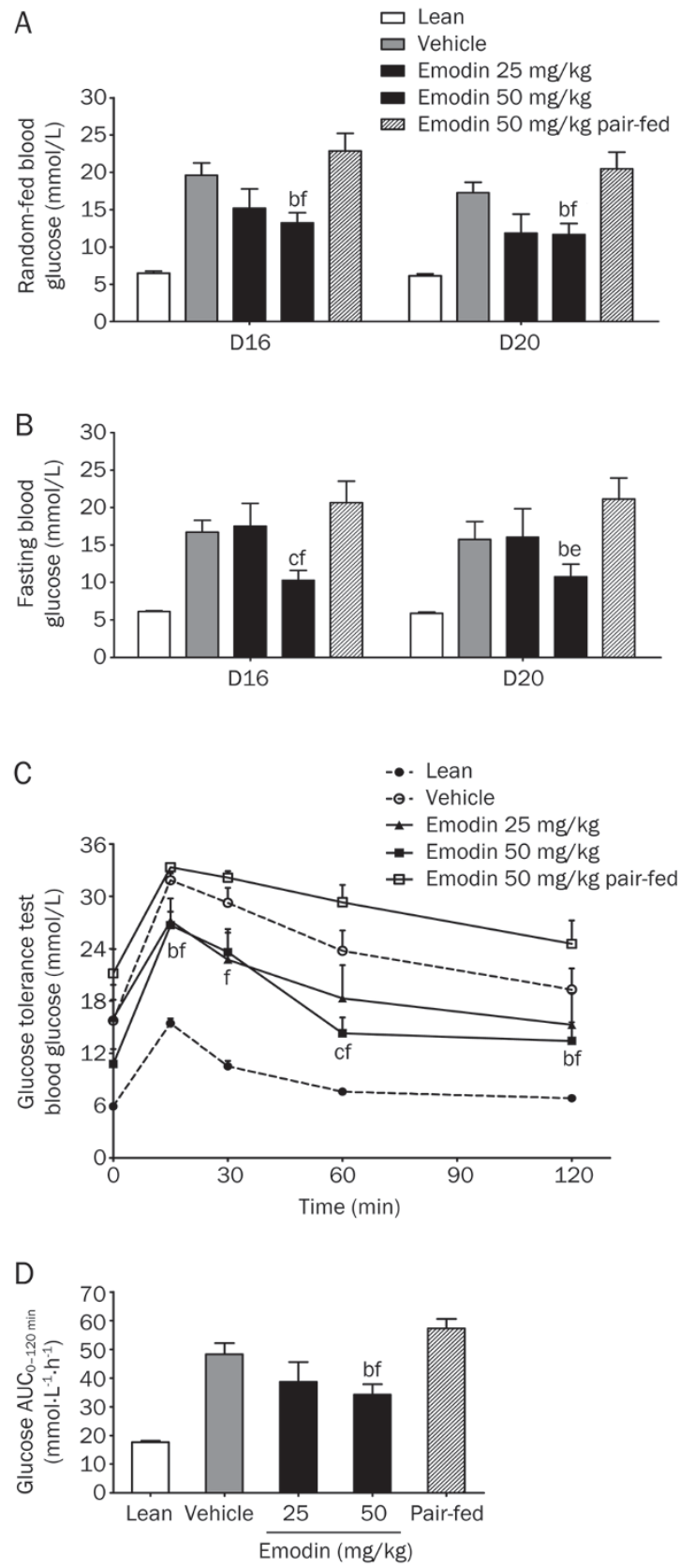

Figure 4. Emodin lowered blood glucose and improved the glucose tolerance of $o b / o b$ mice. $o b / o b$ mice were subjected to intraperitoneal injection twice daily with vehicle (0.5\% Tween 80$), 25 \mathrm{mg} / \mathrm{kg}$ emodin or $50 \mathrm{mg} / \mathrm{kg}$ emodin for $26 \mathrm{~d}$. A pair-fed group was set by providing the ob/ ob mice each day with the amount of food eaten by freely fed $50-\mathrm{mg} / \mathrm{kg}$ emodin-treated mice. Random-fed blood glucose concentrations (A) and fasting blood glucose concentrations (B) were measured on day 16 and day 20. Glucose tolerance $(C$ and $D)$ was determined on day 20 of the treatment. Values are expressed as the mean \pm SEM. ${ }^{b} P<0.05,{ }^{c} P<0.01$ vs vehicle group; ${ }^{\mathrm{e}} P<0.05,{ }^{\mathrm{f}} P<0.01$ vs $50-\mathrm{mg} / \mathrm{kg}$ emodin pair-fed group; $n=8$.

with the vehicle control mice (Figure 5A). The total cholesterol levels of emodin and pair-fed mice showed mild reductions but did not reach statistical significance (Figure 5B). Emodin $(25 \mathrm{mg} / \mathrm{kg})$ caused a $15.25 \%$ reduction of the NEFA level
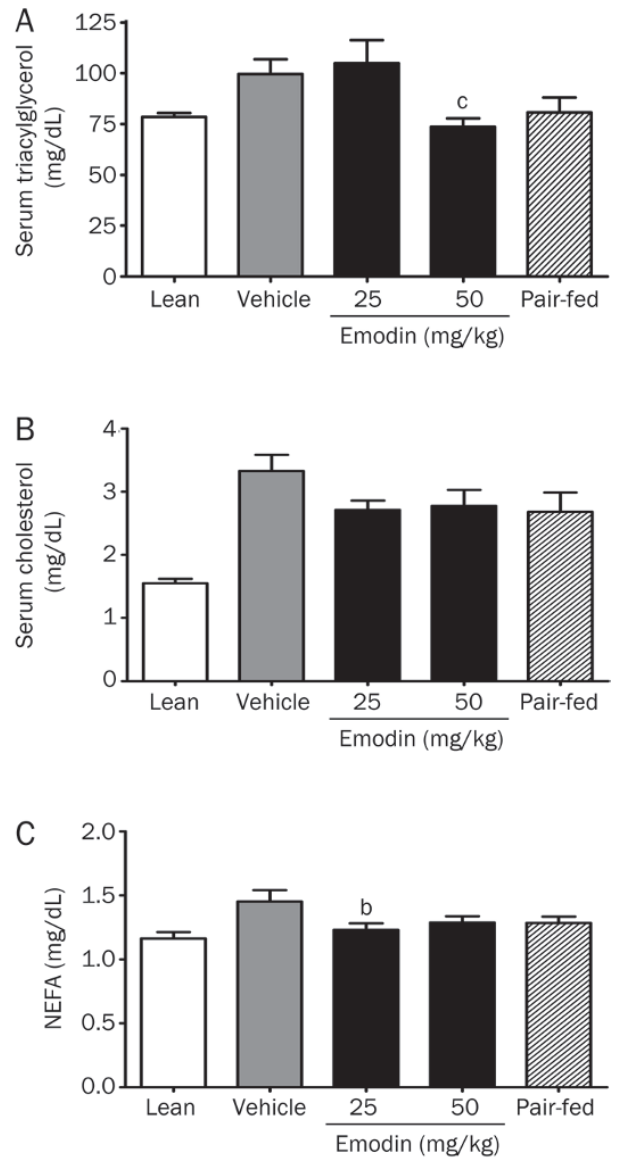

Figure 5. Effects of emodin on serum lipids of $a b / o b$ mice. $o b / o b$ mice were subjected to intraperitoneal injection twice daily with vehicle $(0.5 \%$ Tween 80), $25 \mathrm{mg} / \mathrm{kg}$ emodin or $50 \mathrm{mg} / \mathrm{kg}$ emodin for $26 \mathrm{~d}$. A pair-fed group was set by providing the ob/ob mice each day with the amount of food eaten by freely fed 50-mg/kg emodin-treated mice. Serum triacylglycerol (A), cholesterols (B) and NEFA (C) concentrations were evaluated at the end of the treatment period. Data are expressed as the mean \pm SEM. ${ }^{b} P<0.05,{ }^{c} P<0.01$ vs vehicle group; $n=8$.

$(P<0.05)$. The NEFA concentrations of $50-\mathrm{mg} / \mathrm{kg}$ emodintreated and pair-fed mice were reduced by $11.15 \%$ and $11.60 \%$, respectively, although these values did not reach statistical significance (Figure 5C).

Long-term treatment with emodin lowered the appetite and body weight of $o b / o b$ mice. The food intakes of the 25- and $50-\mathrm{mg} / \mathrm{kg}$ emodin-treated mice were significantly decreased, by $26.26 \%$ and $26.31 \%(P<0.01)$, respectively, compared with the vehicle-treated animals (Figure 6A). The $o b / o b$ mice treated with 25 or $50 \mathrm{mg} / \mathrm{kg}$ of emodin showed steady declines in body weight; the body weight gains on day 20 were reduced by $63.30 \%$ and $66.06 \%(P<0.01)$, respectively, and the emodin pair-fed mice also showed a similar decreased body weight gain (Figure 6B). Furthermore, both 25 and $50 \mathrm{mg} / \mathrm{kg}$ of emodin caused a reduction in mesenteric fat pad weights by $37.8 \%(P<0.01)$, whereas the pair-fed mice showed a reduction of $28.48 \%(P<0.01)$ (Figure $6 \mathrm{C})$. The perirenal fat pad weight in the $50-\mathrm{mg} / \mathrm{kg}$ emodin-treated $o b / \mathrm{ob}$ mice was reduced by 
A

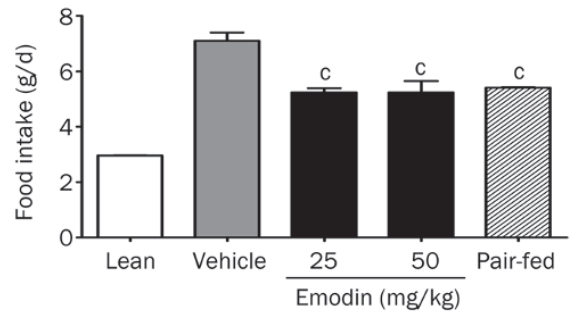

$\mathrm{B}$

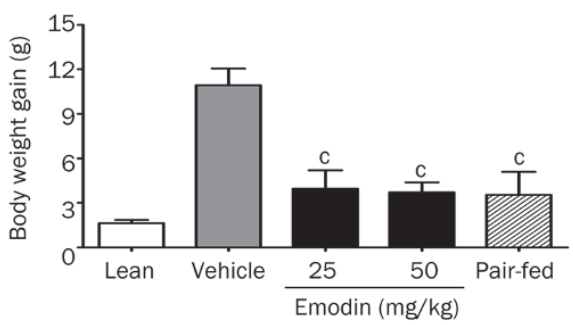

C

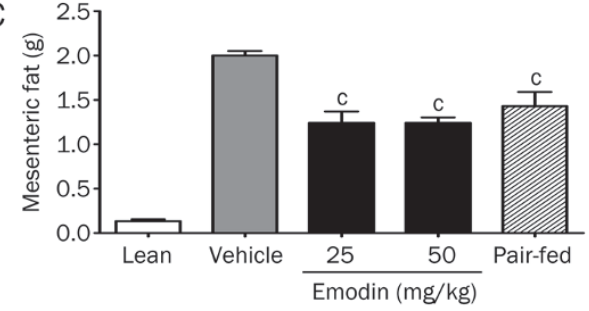

D

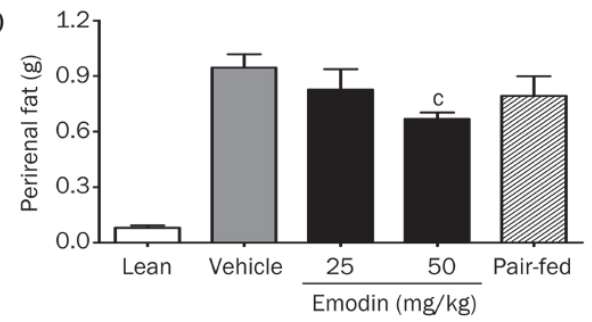

Figure 6. Emodin decreased the food intake (A), body weight gain (B), mesenteric fat weight $(C)$ and perirenal fat weight (D) of ob/ob mice. $o b / o b$ mice were subjected to intraperitoneal injection twice daily with vehicle (0.5\% Tween 80 ), $25 \mathrm{mg} / \mathrm{kg}$ emodin or $50 \mathrm{mg} / \mathrm{kg}$ emodin for $26 \mathrm{~d}$. A pair-fed group was set by providing the ob/ob mice each day with the amount of food eaten by freely fed $50-\mathrm{mg} / \mathrm{kg}$ emodin-treated mice. Values are expressed as the mean \pm SEM. ${ }^{c} P<0.01$ vs vehicle group; $n=8$.

$29.26 \%(P<0.01)$ compared with the vehicle-treated mice, whereas no significant reduction was found in the pair-fed mice (Figure 6D).

The effects of long-term treatment with emodin on the mRNA expression of adiponectin and PPARY in the mesenteric fat of $o b / o b$ mice were also studied. As shown in Figures $7 \mathrm{~A}$ and $7 \mathrm{~B}$, the treatment of $o b / o b$ mice with $50 \mathrm{mg} / \mathrm{kg}$ of emodin for $26 \mathrm{~d}$ significantly increased adiponectin and PPARY mRNA levels by $233.2 \%$ and $282.9 \%$, respectively, compared with the vehicle group $(P<0.01)$.

\section{Discussion}

Adipocyte dysfunction has been shown to play key roles in the development of insulin resistance, obesity and type 2 diabetes.
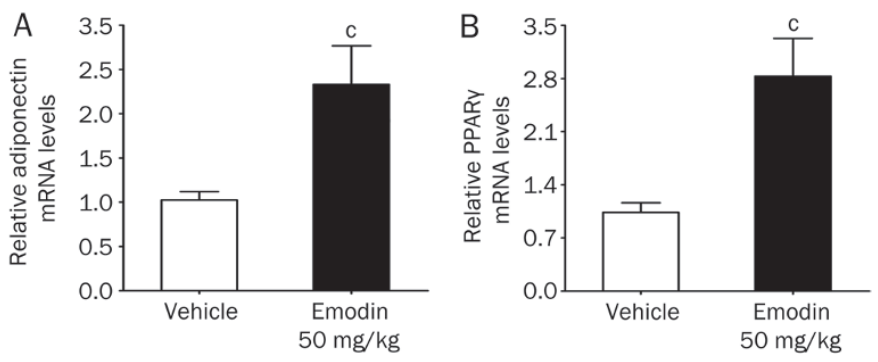

Figure 7. Emodin increased the mRNA levels of adiponectin (A) and PPARY (B) in the mesenteric fat of $o b / o b$ mice. $o b / o b$ mice were subjected to intraperitoneal injection twice daily with vehicle $(0.5 \%$ Tween 80$)$ or emodin $(50 \mathrm{mg} / \mathrm{kg}$ ) for $26 \mathrm{~d}$. The relative mRNA levels of adiponectin and PPARY in the mesenteric fat were determined by real-time PCR at the end of the treatment period. Values are expressed as the fold increase over the values for the vehicle group. ${ }^{\mathrm{c}} P<0.01$ vs vehicle group; $n=7$.

The inhibition of $11 \beta$-HSD1 in adipose tissue was expected to ameliorate adipocyte dysfunction and exert a beneficial effect on type 2 diabetes or metabolic diseases ${ }^{[5,13]}$. In our previous study, emodin was demonstrated to be a potent and selective $11 \beta$-HSD1 inhibitor and ameliorate metabolic disorders in diet-induced obese mice ${ }^{[21]}$. However, its effect on adipocyte dysfunction has been unclear until now. In the present study, we demonstrated that emodin inhibited 11ß-HSD1 activity in 3T3-L1 adipocytes and ameliorated inactive glucocorticoidcaused adipocyte dysfunction. Moreover, emodin improved the glycemic control and ameliorated other metabolic disorders in $o b / o b$ mice.

$11 \beta$-HSD1 is a bidirectional enzyme (dehydrogenase and oxoreductase) that functions predominantly as an oxoreductase in intact cells and catalyzes glucocorticoids to become active; its action is dependent on the NAPDH concentration in the endoplasmic reticulum ${ }^{[23]}$. Our previous study showed that emodin inhibited recombinant $11 \beta$-HSD1 activity in microsome fractions prepared from HEK-293 cells stably transfected with either mouse or human $11 \beta$-HSD1, with $\mathrm{IC}_{50}$ values of 86 and $186 \mathrm{nmol} / \mathrm{L}$, respectively. Emodin also exhibited low inhibitory activity against mouse or human $11 \beta$ HSD2 with the $\mathrm{IC}_{50}$ higher than $1 \mathrm{mmol} / \mathrm{L}^{[21]}$. In this study, the inhibitory effect of emodin on the oxoreductase activity of 11 $\beta$-HSD1 was determined in 3T3-L1 adipocytes in the absence of exogenous $\mathrm{NAPDH}$, and the $\mathrm{IC}_{50}$ values after $1 \mathrm{~h}$ or $24 \mathrm{~h}$ of treatment were 7.24 and $4.20 \mu \mathrm{mol} / \mathrm{L}$, respectively. Therefore, emodin inhibited the oxoreductase activity of $11 \beta$ HSD1 in intact 3T3-L1 adipocytes, although its efficacy is less than that against recombinant mouse $11 \beta-H S D 1$ in microsome fractions; this lower efficacy might be due to the compound's limited penetration of the cell membrane or the restricted NADPH levels in intact cells.

Excess glucocorticoid causes visceral obesity owing to the acceleration of preadipocyte differentiation and adipocyte fat accumulation ${ }^{[24]}$. It has been demonstrated that the differentiation of 3T3-L1 preadipocytes can be induced by both active and inactive glucocorticoids, such as dexamethasone, 
corticosterone and 11-DHC, and endogenous $11 \beta-H S D 1$ oxoreductase activity was expected to be required for differentiation induced by 11-DHC, an inactive glucocorticoid ${ }^{[25]}$. Thus, we examined the effect of emodin on the differentiation of 3T3-L1 preadipocytes induced by dexamethasone, corticosterone and 11-DHC. Emodin suppressed the adipogenesis induced by 11-DHC but not by corticosterone or dexamethasone in 3T3-L1 cells, which further confirms that emodin inhibits the oxoreductase activity of 11 $\beta$-HSD1 in 3T3-L1 cells.

Glucocorticoid receptors are highly expressed in adipocytes. Excessive glucocorticoid action in adipose tissue caused by either high circulating glucocorticoid levels or high local $11 \beta-$ HSD1 expression and activity can negatively regulate a number of cellular glucose and lipid metabolic processes in adipocytes $^{[5]}$. Glucocorticoids directly induce insulin resistance, which is mainly associated with the manifestation of impaired insulin-stimulated glucose uptake ${ }^{[26]}$ and increased lipolysis, leading to elevated FFA release ${ }^{[27]}$; glucocorticoids also cause abnormalities in the release of adipokines, such as adiponec$\operatorname{tin}^{[28]}$. Our present study showed that both corticosterone and 11-DHC can impair the insulin-stimulated glucose uptake, enhance lipolysis, and suppress adiponectin release in 3T3L1 adipocytes. All cellular disorders caused by 11-DHC were partly reversed by emodin, whereas no significant changes were observed in the corticosterone-treated group. Because $11 \beta$-HSD1 is highly expressed in mature adipocytes ${ }^{[25]}$, these results suggest that emodin can diminish adipocyte dysfunction by reducing local glucocorticoid action through inhibition of 11ß-HSD1, which may ameliorate the whole body metabolic disorders in obesity or type 2 diabetes.

Our previous studies showed that emodin lowered blood glucose, improved insulin resistance and dyslipidemia, and decreased body weight and central fat mass in DIO mice ${ }^{[21]}$. In the present study, we further evaluated the in vivo effects of emodin on $o b / o b$ mice, a genetic murine model of type 2 diabetes, which displayed hyperglycemia, hyperinsulinemia, dyslipidemia, obesity and insulin resistance ${ }^{[29]}$. The results showed that 26 days of treatment with emodin caused a significant reduction in $11 \beta$-HSD1 activity in the mesenteric fat of $o b / o b$ mice, which confirmed that emodin inhibits 11/-HSD1 in adipose tissues in vivo. Moreover, emodin lowered the blood glucose levels, improved glucose tolerance, ameliorated dyslipidemia, and decreased body weight and food intake in $o b /$ $o b$ mice. Because glucocorticoids are orexigenic and adipose tissue-specific overexpression of $11 \beta-H S D 1$ has been shown to cause hyperphagia ${ }^{[8,30]}$, the reduced food intake caused by emodin was expected. This finding is in line with our previous findings in DIO mice and other reports on the $11 \beta-H S D 1$ inhibitor $^{[31]}$. To exclude the metabolic changes caused by the reduced food intake, a pair-fed group corresponding to the $50-\mathrm{mg} / \mathrm{kg}$ emodin-treated group was set up. The beneficial changes in lipid profile, body weight, and fat mass in the $50-\mathrm{mg} / \mathrm{kg}$ emodin group were similar to those in the pairfed group, which suggests that those improvements might be due to the reduced food intake. However, although the food intakes were similar, $50 \mathrm{mg} / \mathrm{kg}$ of emodin still significantly decreased both the random-fed and fasting blood glucose levels, and it also resulted in an improved oral glucose tolerance compared with the pair-fed group, which indicated that the glucose lowering effect of emodin on $o b / o b$ mice is not only due to reduced food intake; other mechanisms, such as the inhibition of $11 \beta$-HSD1, were also involved.

It has been reported that the mRNA expression of adiponectin and PPARY are increased in epididymal adipose tissue in $11 \beta$-HSD1 knockout mice ${ }^{[13]}$. Owing to the role of glucocorticoids in adiponectin secretion decreases ${ }^{[28]}$, it was not surprising to find that $11 \beta-H S D 1$ inhibition is involved in increasing adiponectin content. The present study demonstrates that long-term treatment with emodin increased adiponectin mRNA expression in mesenteric adipose tissue, which may be attributable to the amelioration of metabolic disorders by emodin in $o b / o b$ mice. PPAR $\gamma$ is a transcription factor closely related to insulin sensitivity, and its activation promotes preadipocyte differentiation and increases adipocyte glucose uptake $^{[32]}$. Chronic emodin administration increased PPARY mRNA expression in mesenteric adipose tissue. Although the correlation between the increased PPARY expression and the $11 \beta$-HSD1-inhibitory effect of emodin is unclear, PPARY is clearly involved in the anti-diabetic effect of emodin.

In conclusion, our study demonstrates that emodin inhibits 11ß-HSD1 activity in 3T3-L1 adipocytes and improves inactive glucocorticoid-induced adipocyte dysfunction. The administration of emodin improved glycemic control and ameliorated other metabolic disorders in $o b / o b$ mice, possibly owing to the inhibition of $11 \beta$-HSD1 activity in adipose tissue.

\section{Acknowledgements}

This study was supported by the National Basic Research Program of China (973 Program, 2009CB522300) and National Science \& Technology Major Project "Key New Drug Creation and Manufacturing Program", China (2009ZX09103-061)and the National Natural Science Foundation of China (30873106).

\section{Author contribution}

Ying LENG designed the study; Yue-jing WANG, Su-ling HUANG, Ying FENG, and Meng-meng Ning performed the research; and Yue-jing WANG, Su-ling HUANG, and Ying LENG wrote the paper.

\section{References}

1 Rosen ED, Spiegelman BM. Adipocytes as regulators of energy balance and glucose homeostasis. Nature 2006; 444: 847-53.

2 Guilherme A, Virbasius JV, Puri V, Czech MP. Adipocyte dysfunctions linking obesity to insulin resistance and type 2 diabetes. Nat Rev Mol Cell Biol 2008; 9: 367-77.

3 Beauregard C, Dickstein G, Lacroix A. Classic and recent etiologies of Cushing's syndrome: diagnosis and therapy. Treat Endocrinol 2002; 1: 79-94.

4 Seckl JR, Walker BR. Minireview: 11beta-hydroxysteroid dehydrogenase type 1- a tissue-specific amplifier of glucocorticoid action. Endocrinology 2001; 142: 1371-6.

5 Morton NM. Obesity and corticosteroids: 11beta-hydroxysteroid type 1 as a cause and therapeutic target in metabolic disease. Mol Cell 
Endocrinol 2010; 316: 154-64.

6 Hollis G, Huber R. 11beta-Hydroxysteroid dehydrogenase type 1 inhibition in type 2 diabetes mellitus. Diabetes Obes Metab 2011; 13: $1-6$.

7 Westerbacka J, Yki-Jarvinen H, Vehkavaara S, Hakkinen AM, Andrew $\mathrm{R}$, Wake DJ, et al. Body fat distribution and cortisol metabolism in healthy men: enhanced 5 beta-reductase and lower cortisol/cortisone metabolite ratios in men with fatty liver. J Clin Endocrinol Metab 2003; 88: 4924-31.

8 Masuzaki H, Paterson J, Shinyama H, Morton NM, Mullins JJ, Seckl $\mathrm{JR}$, et al. A transgenic model of visceral obesity and the metabolic syndrome. Science 2001; 294: 2166-70.

9 Masuzaki H, Yamamoto H, Kenyon CJ, Elmquist JK, Morton NM, Paterson JM, et al. Transgenic amplification of glucocorticoid action in adipose tissue causes high blood pressure in mice. J Clin Invest 2003; 112: 83-90.

10 Paterson JM. Metabolic syndrome without obesity: Hepatic overexpression of 11-hydroxysteroid dehydrogenase type 1 in transgenic mice. Proc Natl Acad Sci U S A 2004; 101: 7088-93.

11 Kotelevtsev Y, Holmes MC, Burchell A, Houston PM, Schmoll D, Jamieson $\mathrm{P}$, et al. 11Beta-hydroxysteroid dehydrogenase type 1 knockout mice show attenuated glucocorticoid-inducible responses and resist hyperglycemia on obesity or stress. Proc Natl Acad Sci U S A 1997; 94: 14924-9.

12 Morton NM, Holmes MC, Fievet C, Staels B, Tailleux A, Mullins JJ, et al. Improved lipid and lipoprotein profile, hepatic insulin sensitivity, and glucose tolerance in 11beta-hydroxysteroid dehydrogenase type 1 null mice. J Biol Chem 2001; 276: 41293-300.

13 Morton NM, Paterson JM, Masuzaki H, Holmes MC, Staels B, Fievet $\mathrm{C}$, et al. Novel adipose tissue-mediated resistance to diet-induced visceral obesity in 11beta-hydroxysteroid dehydrogenase type 1-deficient mice. Diabetes 2004; 53: 931-8.

14 Kershaw EE, Morton NM, Dhillon H, Ramage L, SeckI JR, Flier JS. Adipocyte-specific glucocorticoid inactivation protects against dietinduced obesity. Diabetes 2005; 54: 1023-31.

15 Wang HH, Chung JG. Emodin-induced inhibition of growth and DNA damage in the Helicobacter pylori. Curr Microbiol 1997; 35: 262-6.

16 Huang Q, Lu G, Shen HM, Chung MC, Ong CN. Anti-cancer properties of anthraquinones from rhubarb. Med Res Rev 2007; 27: 609-30.

17 Chang $\mathrm{CH}$, Lin CC, Yang JJ, Namba T, Hattori M. Anti-inflammatory effects of emodin from ventilago leiocarpa. Am J Chin Med 1996; 24: 139-42.

18 Huang HC, Chang JH, Tung SF, Wu RT, Foegh ML, Chu SH. Immunosuppressive effect of emodin, a free radical generator. Eur J Pharmacol 1992; 211: 359-64.

19 Woo SW, Nan JX, Lee SH, Park EJ, Zhao YZ, Sohn DH. Aloe emodin suppresses myofibroblastic differentiation of rat hepatic stellate cells in primary culture. Pharmacol Toxicol 2002; 90: 193-8.

20 Heo SK, Yun HJ, Park WH, Park SD. Emodin inhibits TNF-alphainduced human aortic smooth-muscle cell proliferation via caspaseand mitochondrial-dependent apoptosis. J Cell Biochem 2008; 105: 70-80.

21 Feng Y, Huang SL, Dou W, Zhang S, Chen JH, Shen Y, et al. Emodin, a natural product, selectively inhibits 11 beta-hydroxysteroid dehydrogenase type 1 and ameliorates metabolic disorder in diet-induced obese mice. Br J Pharmacol 2010; 161: 113-26.

22 Hu X, Feng Y, Liu X, Zhao XF, Yu JH, Yang YS, et al. Effect of a novel non-thiazolidinedione peroxisome proliferator-activated receptor alpha/gamma agonist on glucose uptake. Diabetologia 2007; 50: 1048-57.

23 Hewitt KN, Walker EA, Stewart PM. Minireview: hexose-6-phosphate dehydrogenase and redox control of 11 \{beta\}-hydroxysteroid dehydrogenase type 1 activity. Endocrinology 2005; 146: 2539-43.

24 Seckl JR, Morton NM, Chapman KE, Walker BR. Glucocorticoids and 11beta-hydroxysteroid dehydrogenase in adipose tissue. Recent Prog Horm Res 2004; 59: 359-93.

25 Kim J, Temple KA, Jones SA, Meredith KN, Basko JL, Brady MJ. Differential modulation of 3T3-L1 adipogenesis mediated by 11betahydroxysteroid dehydrogenase-1 levels. J Biol Chem 2007; 282: 11038-46.

26 Sakoda H, Ogihara T, Anai M, Funaki M, Inukai K, Katagiri $\mathrm{H}$, et al. Dexamethasone-induced insulin resistance in 3T3-L1 adipocytes is due to inhibition of glucose transport rather than insulin signal transduction. Diabetes 2000; 49: 1700-8.

27 Divertie GD, Jensen MD, Miles JM. Stimulation of lipolysis in humans by physiological hypercortisolemia. Diabetes 1991; 40: 1228-32.

28 Shi JH, Du WH, Liu XY, Fan YP, Hu XL, Zhou HY, et al. Glucocorticoids decrease serum adiponectin level and WAT adiponectin mRNA expression in rats. Steroids 2010; 75: 853-8.

29 Herberg L, Leiter EH, editor. Obesity/diabetes in mice with mutations in the leptin or leptin receptor genes. Amsterdam Harwood Academic 2001.

30 Cavagnini F, Croci M, Putignano P, Petroni ML, Invitti C. Glucocorticoids and neuroendocrine function. Int J Obes Relat Metab Disord 2000; 24: S77-9.

31 Wang SJ, Birtles S, de Schoolmeester J, Swales J, Moody G, Hislop $D$, et al. Inhibition of 11 beta-hydroxysteroid dehydrogenase type 1 reduces food intake and weight gain but maintains energy expenditure in diet-induced obese mice. Diabetologia 2006; 49: 1333-7.

32 Ferre P. The biology of peroxisome proliferator-activated receptors: relationship with lipid metabolism and insulin sensitivity. Diabetes 2004; 53: S43-50. 